\title{
Engineering Accreditation in Canada
}

\author{
Nader G. Zamani, Ph.D. ${ }^{1}$, Jacqueline Stagner, Ph.D. ${ }^{1}$ \\ ${ }^{1}$ University of Windsor, Canada, zamani@uwindsor.ca, stagner@uwindsor.ca
}

\begin{abstract}
The goal of this paper is to provide the engineering community in the Latin American and Caribbean countries an informative, yet brief description of the engineering accreditation issues and practices in Canada. This is in light of the inquiries by universities outside of Canada trying to develop articulations with the Canadian engineering schools. Some practices that may seem to be straightforward and feasible in the rest of the world may face significant challenges by the engineering programs offered in Canada.
\end{abstract}

Keywords - Engineering, Accreditation, Accreditation Unit, Graduate Attributes

Digital Object Identifier (DOI):

http://dx.doi.org/10.18687/LACCEI2015.1.1.012

ISBN: 13 978-0-9822896-8-6

ISSN: $2414-6668$

13 ${ }^{\text {th }}$ LACCEI Annual International Conference: “Engineering Education Facing the Grand Challenges, What Are We Doing?” July 29-31, 2015, Santo Domingo, Dominican Republic 


\title{
Engineering Accreditation in Canada
}

\author{
Nader G. Zamani, Ph.D. P.Eng, Jacqueline Stagner, Ph.D. P.Eng. \\ University of Windsor, Canada, zamani@uwindsor.ca, stagner@uwindsor.ca
}

\begin{abstract}
The goal of this paper is to provide the engineering community in the Latin American and Caribbean countries an informative, yet brief description of the engineering accreditation issues and practices in Canada. This is in light of the inquiries by universities outside of Canada trying to develop articulations with the Canadian engineering schools. Some practices that may seem to be straightforward and feasible in the rest of the world may face significant challenges by the engineering programs offered in Canada.
\end{abstract}

Keywords-Engineering, Accreditation, Accreditation Unit, Graduate Attributes

\section{INTRODUCTION}

The engineering profession in Canada is self-regulated. Each of the provinces in Canada has their own governing body which regulates, monitors, and coordinates the engineering profession in that province. For example, in Ontario, where the University of Windsor is located, "Professional Engineers Ontario (PEO) [1] is the regulatory body. Although these provincial organizations closely communicate with each other, they are deemed to be independent. They have a great influence in how the business of engineering is conducted and how engineering education is delivered in Canada. These provincial regulators form EngineersCanada [2] (as a national body) which licenses more than 270,000 engineers working in the nation. EngineersCanada manages the affairs of the Canadian Engineering Accreditation Board (CEAB) which is responsible for reviewing the engineering programs in the nation and granting of the accreditation designations. In principle, all programs have to be reviewed on a seven year cycle (maximum of seven years). In Canada, CEAB is the counterpart of ABET [3] in the U.S., however it has a completely different governance and reporting structure. In the U.S. (and perhaps other countries), universities can have engineering programs offering degrees whereas in Canada, this is not permitted. Even the use of the term "engineering" by businesses requires the approval of the provincial regulators such as PEO in Ontario. The accreditation of engineering programs is based in the principle of the "weakest link" which is described in later sections of this paper. The weakest link approach puts very stringent constraints on the curriculum delivery.

\section{THE LOGISTICS OF THE VISIT}

The universities that seek accreditation for their engineering program(s) have to formally invite CEAB to visit their institution and they are responsible for the entire cost of the visit. This usually occurs at least one year before the visit.
At that point, EngineersCanada arranges for a visiting team Chair who then selects members for different disciplines and his/her Vice Chair. Depending on the size of the program, each subcommittee of the visiting team consists of one to three faculty members from different universities who are referred to as "program visitors". The professional engineering association also assigns a number of individuals who are referred to as "general visitors". There is also the opportunity for other universities (anywhere in or outside of Canada) to request participation as observers. This is particularly useful for those who may be seeking accreditation in the future. The universities being visited must agree with the composition of the visiting team. Six weeks prior to the visit, an electronic copy of the accreditation questionnaire - an extensive document containing the details of all relevant information for the program - is submitted to EngineersCanada.

Ordinarily the visit takes three days. In the first day, the visiting team meets as a group and scrutinizes the extensive documentation that is prepared for each program to be accredited. At this time, the accreditation questionnaire that was sent to the visiting team in advance is made available to the visiting team, as well as additional supporting documentation. For instance, a package of material is compiled for each course in the program curriculum. This can include copies of the course syllabus, lecture notes, assignments, laboratories, homework, projects, tests, and exams, marking schemes or grading rubrics for these assessments, and samples of student work for each.

On days two and three of the visit, the team (the Chair, Vice-Chair, program visitors, and general visitors of the visiting team) interviews all of the stakeholders at the university. This includes meetings with the senior administration of the institution, leadership team of the Faculty (such as the Dean, Associate Dean, and the Department Heads), the individual faculty members, technical staff, support staff, and a wide representation of the undergraduate student body, and the teaching assistants.

The purpose of interviewing the senior administration (President and the Vice-Presidents, and several Deans) is to gauge the level of commitment of the institution to the Engineering program. The interview with the department Heads and the individual faculty members are intended to reveal any concerns with curriculum and to make constructive suggestions. The visitors are interested in the views and opinions of the students as they are the primary clientele of the programs delivered. During the three-day fact-finding mission, the visitors also have extensive tours of the teaching laboratories, the computing facilities, and the teaching/learning infrastructure at the university. In an exit

$13^{\text {th }}$ LACCEI Annual International Conference: “Engineering Education Facing the Grand Challenges, What Are We Doing?” July 29-31, 2015, Santo Domingo, Dominican Republic ISBN: 13 978-0-9822896-8-6 ISSN: $2414-6668$ 
interview on the last day of the visit, they summarize their findings and provide some feedback to the Faculty Management Group. It is important to point out that the visitors do not recommend accreditation. They merely report the results of this audit to the Canadian Engineering Accreditation Board. The Board assigns a member to review the results and in turn to make (or not to make) a recommendation for granting accreditation. The decision is usually made and relayed to the university about four months after the visit. Accreditation can be granted at different levels. For example, the best case scenario is " $6 \mathrm{~V}$ " meaning that the program is accredited for six more years. The next best scenario is " $3 \mathrm{R}$ " meaning that there were some deficiencies identified but the program is accredited for three more years, at which time a report by the institution is required outlining how the deficiencies were addressed. The worst scenario is " $\mathrm{T}$ " or " $1 \mathrm{~T}$ " which means that the program is terminated immediately, or after one year. This type of decision is very rare and is usually appealed by the institution.

The criteria against which the programs are assessed are both input-based (considering Accreditation Units) and outcomes-based (considering Graduate Attributes), as discussed in the following sections.

\section{THE ACCREDIATION UNIT (AU)}

As far as the CEAB is concerned, an undergraduate engineering student must be exposed to a balanced curriculum involving natural sciences, mathematics, engineering science, engineering design, and complimentary studies. Although, some of the above terminologies are obvious, and there are formal definitions by $\mathrm{CEAB}$ which can be found in their literature, examples of them are listed below for the sake of completeness.

a) Natural Science: physics and chemistry.

b) Mathematics: self-explanatory.

c) Engineering Science: electric circuits, stress analysis, heat transfer etc. Effectively, use of natural sciences and mathematics to solve real engineering problems.

d) Engineering Design: an open ended problem which involves an iterative optimized solution.

e) Complementary Studies: subjects involving humanities, arts, economics, social sciences, history, ethics and law.

In order to assess the level of exposure to such topics, these must be quantified by some means. The "currency" for achieving this is referred to as AU or the "Accreditation Unit." The easiest way to explain this concept is to consider four fictitious courses and, after making some assumption about them, to calculate the AUs for each. It is assumed that a semester is 12 weeks long.

MATH 101: A first semester calculus course which meets three hours a week and has a one hour tutorial per week.
CHEM 100: A first semester chemistry course which meets three hours a week and has a two hour lab per week.

ENGN 201: A second year engineering economy course which has a $100 \%$ complementary studies component. The course meets three hours a week and has no lab or tutorial component.

MECH 301: A third year course in stress analysis which has a $25 \%$ design component. This course meets four hours a week and has two hours of laboratory/tutorial per week.

For the AU calculations, the course weight is calculated as:

academic credit weight $=$ number of lecture hours per week + 0.5(number of lab or tutorial hours per week)

\section{AU Calculation for MATH 101:}

The credit weight for this course is $3+0.5 \times 1=3.5$. Since the course is twelve weeks long, the AU count for the course is $12 \times 3.5=42$. Since MATH 101 has no components beside mathematics, the entire 42 AUs count as "mathematics".

\section{AU Calculation for CHEM 100:}

The credit weight for this course is $3+0.5 \times 2=4$. Course duration of 12 weeks gives an AU count of $12 \times 4=48$. A chemistry course covers only natural sciences.

\section{AU Calculation for ENGN 201:}

The credit weight is $3+0.5 \times 0=3$. A course duration of 12 weeks gives an $\mathrm{AU}$ count of $12 \times 3=36$. A course such as engineering economy is considered to be entirely "complementary studies" as it has very little mathematics and no natural sciences.

\section{AU Calculation for MECH 301:}

The credit weight the course is $4+0.5 \times 2=5$. A twelve week semester gives an AU count of $12 \times 5=60$. Since $25 \%$ of the course involves design, $60 \times 25 \%=15$ AUs can be earmarked for design purposes (as will be seen later) and the remaining 45 AUs count towards engineering science.

These calculations needs to be carried out for every single course that a student takes to obtain his/her degree in the program. There are some additional stringent constraints attached which also need to be considered. To give the reader two specific examples, courses that involve any design component must be taught by a Professional Engineer in Canada. If this condition is not met, the design component of those courses cannot be used for the "grand total" calculation (to be described later). There is a further constraint that even 
in the case of engineering science, not more than a certain number of AUs can be taught by instructors without a PEng designation.

A common misconception is that the basic courses in natural sciences and mathematics must be taught by instructors with terminal advanced degrees in those fields. This however is not the case. The expectation is that, regardless of the academic qualifications of the instructors, the content be delivered as if it was being presented to students in a science department. To put it in a different way, the instructor (who may be an engineer) should not dilute/simplify the content because it is being delivered to engineering students.

In addition to the points raised above, there are other factors that have to be taken into consideration. For example, the engineering program offered should not rely on a single individual for course offerings.

There may be courses which do not have a traditional lecture delivery mode. As an example, in Canada, every engineering student in his/her final year must be involved in a capstone projects. Such projects are open ended design problems where the students work as a team and do not involve the traditional class room activities. Since the credit weight explained earlier is not applicable, CEAB proposes the use of a number called the " $\mathrm{K}$ " factor [4], which is calculated as follows:

Sum of AU for all compulsory courses which used the AU calculation method

\section{$\mathrm{K}=\mathrm{\text {Sumofunitsdefinedbytheinstitution }}$ for the same courses}

\section{THE MINMUM PATH BASED ON AUS}

There are strict guidelines for meeting the constraints set by CEAB. These minimum expectations are summarized below and are taken from [4] verbatim.

Minimum curriculum components: An engineering program must include the minimum for the entire curriculum and for each of its components.

- The entire program must include a minimum of $1,950 \mathrm{AU}$

- Mathematics: Minimum 195 AU

- Natural sciences: Minimum 195 AU

- Mathematics and natural sciences combined: Minimum 420 AU

- Engineering science: Minimum 225 AU

- Engineering design: Minimum 225 AU

- Engineering science and engineering design combined: Minimum 900 AU

- Complementary Studies: Minimum 225 AU

- Laboratory experience and safety procedures instruction
A sample of a portion of an AU table that calculates the $\mathrm{AU}$ totals for a fictitious undergraduate engineering program is shown in Table 1. It can be seen that the instructor for the MECH 201 course does not have a PEng licence, since the "Specific AU" values for Engineering Science and Engineering Design have been set to zero. Table 1 also demonstrates the way in which the "minimum path" is calculated. That is, within the list of elective courses, one must determine the minimum values for each of the components Mathematics (Math), Natural Science (NS), Complementary Studies (CS), Engineering Science (ES), and Engineering Design (ED). If there are seven elective courses as part of the undergraduate program curriculum, then the seven lowest values in each of the component columns for the elective courses are used to determine the AU totals.

In addition to the above requirements, an accredited program must ensure that certain topics are covered in the curriculum. These are listed below:

1 - Engineering economy

2- The impact of technology on society

3- Subjects dealing with central issues, humanities and social sciences

4- Oral and written communications

5- Health and safety in society

6- Professional ethics, equity and law

7- Sustainable development and environmental awareness

For all practical purposes, in order to be able to deliver an accredited engineering program in Canada, the overwhelming majority of the faculty members such must have a professional engineering (PEng) designation, preferably in the province where the institution is located. Having an engineering license from another jurisdiction (another country) is not an acceptable alternative. Needless to say, the minimum AU requirement is not the only criterion to be met. The visited institution must also demonstrate that sufficient resources and infrastructure are available for the program delivery.

In the past seven years, there has been a major push to follow the American model of ABET and to abandon the AU concept for accreditation. The ABET model is based on "outcomes". There has been considerable resistance by the provincial professional engineering bodies to adopt this approach. However, a compromise has been reached to maintain the AU system for the time being but also to look into the concept of "Graduate Attributes" alongside. In the remaining sections of the paper, the ideas behind the "outcomes-based" accreditation process are explained in detail. 
TABLE 1

SAMPLE AU TABLE

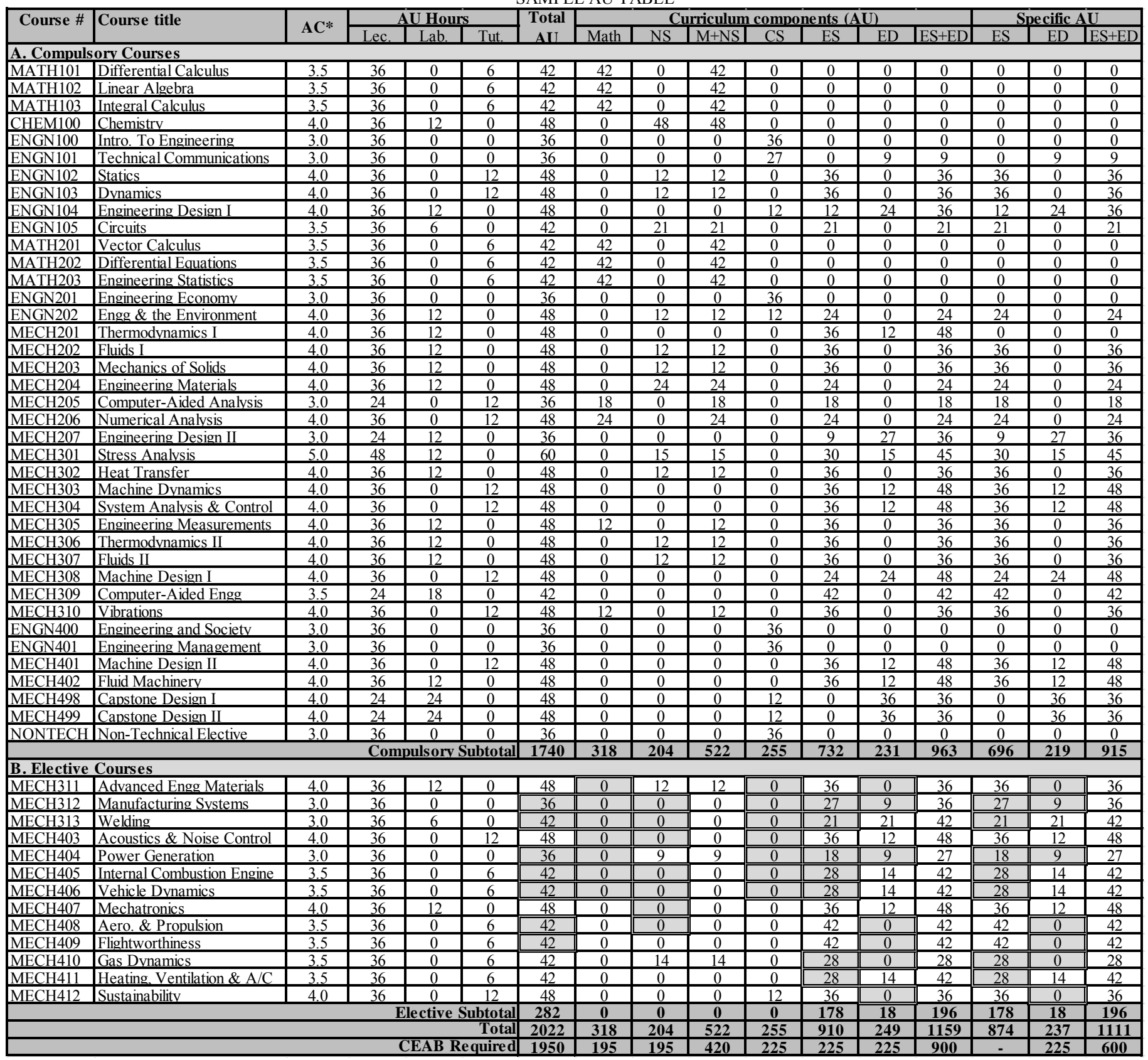

* "AC" refers to Academic Credit, the credit assigned to each course by the institution of higher education.

$13^{\text {th }}$ LACCEI Annual International Conference: "Engineering Education Facing the Grand Challenges, What Are We Doing?" July 29-31, 2015, Santo Domingo, Dominican Republic 


\section{GRADUATE ATTRIBUTES}

In addition to the minimum path approach, as of the fall of 2014, accredited programs must demonstrate that their courses are outcomes-based [4]. The course learning outcomes (CLOs) for each course must show how the course contributes to students' development of twelve Graduate Attributes (GrAtts):

1. A knowledge base for engineering,

2. Problem analysis,

3. Investigation,

4. Design,

5. Use of engineering tools,

6. Individual and team work,

7. Communication skills,

8. Professionalism,

9. Impact of engineering on society and the environment,
10. Ethics and equity,

11. Economics and project management, and

12. Life-long learning.

At this point in time, there is not a requirement for undergraduate engineering programs to demonstrate that all students have achieved all of the GrAtts at a specific level, but that the curriculum provides multiple opportunities to introduce, develop, and apply the GrAtts. The data that are collected for the assessment of CLOs help to inform decisions for continuous improvement of courses and the curriculum.

In order to gain an understanding of the sequence of how courses contribute to students' development of the Graduate Attributes, a curriculum map must be generated. A curriculum map shows graphically when students are developing the twelve graduate attributes. An example of a fictitious curriculum map is shown in Table 2.

TABLE 2

SAMPLE CURRICULUM MAP OF GRADUATE ATTRIBUTES

\begin{tabular}{|c|c|c|c|c|c|c|c|c|}
\hline \multirow{2}{*}{ Graduate Attribute } & \multicolumn{8}{|c|}{ Semester } \\
\hline & 1 & 2 & 3 & 4 & 5 & 6 & 7 & 8 \\
\hline \multirow{6}{*}{ Knowledge base } & MATH101 & MATH103 & MATH201 & MATH202 & MECH301 & MECH306 & MECH401 & MECH402 \\
\hline & MATH102 & CHEM100 & MATH203 & MECH203 & MECH302 & MECH307 & & \\
\hline & ENGN102 & ENGN103 & ENGN202 & MECH204 & MECH303 & MECH308 & & \\
\hline & ENGN105 & & MECH201 & MECH205 & MECH304 & MECH310 & & \\
\hline & & & MECH202 & MECH206 & MECH305 & & & \\
\hline & & & & MECH207 & & & & \\
\hline \multirow{5}{*}{ Problem analysis } & ENGN102 & ENGN101 & ENGN202 & MECH203 & MECH301 & MECH306 & MECH401 & MECH402 \\
\hline & & ENGN103 & MECH201 & MECH204 & MECH302 & MECH307 & MECH498 & MECH499 \\
\hline & & & MECH202 & MECH205 & MECH303 & MECH308 & & \\
\hline & & & & MECH206 & MECH304 & MECH309 & & \\
\hline & & & & & & MECH310 & & \\
\hline \multirow{5}{*}{ Investigation } & & CHEM100 & MECH201 & MECH204 & MECH303 & MECH306 & MECH401 & MECH402 \\
\hline & & & MECH202 & & MECH305 & MECH307 & MECH498 & MECH499 \\
\hline & & & & & & MECH308 & & \\
\hline & & & & & & MECH309 & & \\
\hline & & & & & & MECH310 & & \\
\hline \multirow{3}{*}{ Design } & & $\begin{array}{l}\text { ENGN101 } \\
\end{array}$ & & MECH203 & MECH301 & MECH307 & MECH401 & $\begin{array}{l}\text { MECH499 } \\
\end{array}$ \\
\hline & & ENGN104 & & MECH207 & MECH304 & MECH308 & MECH498 & \\
\hline & & & & & & MECH310 & & \\
\hline \multirow{5}{*}{ Use of engineering tools } & & ENGN101 & & MECH204 & MECH301 & MECH306 & & \\
\hline & & ENGN104 & & MECH205 & MECH302 & MECH309 & & \\
\hline & & & & MECH206 & MECH303 & MECH310 & & \\
\hline & & & & MECH207 & MECH304 & & & \\
\hline & & & & & MECH305 & & & \\
\hline \multirow{3}{*}{ Individual and team work } & & CHEM100 & ENGN202 & & MECH301 & MECH308 & ENGN401 & MECH499 \\
\hline & & $\begin{array}{l}\text { ENGN101 } \\
\end{array}$ & MECH202 & & & & MECH401 & \\
\hline & & & & & & & MECH498 & \\
\hline \multirow{3}{*}{ Communication skills } & ENGN100 & ENGN101 & ENGN202 & MECH203 & MECH301 & & ENGN401 & MECH499 \\
\hline & & ENGN104 & & MECH207 & MECH302 & & MECH498 & \\
\hline & & & & & MECH305 & & & \\
\hline \multirow{3}{*}{ Professionalism } & ENGN100 & ENGN101 & ENGN201 & & & & ENGN400 & MECH499 \\
\hline & & & ENGN202 & & & & ENGN401 & \\
\hline & & & & & & & MECH498 & \\
\hline \multirow{2}{*}{$\begin{array}{l}\text { Impact of engineering on } \\
\text { society and the environment }\end{array}$} & ENGN100 & & ENGN202 & & & MECH310 & ENGN400 & \\
\hline & & & & & & & & \\
\hline \multirow[b]{2}{*}{ Ethics and equity } & ENGN100 & $\begin{array}{l}\text { ENGN101 } \\
\end{array}$ & & & & $\begin{array}{l}\text { MECH } 308 \\
\end{array}$ & $\begin{array}{l}\text { ENGN400 } \\
\end{array}$ & \\
\hline & & & & & & & ENGN401 & \\
\hline \multirow{2}{*}{$\begin{array}{c}\text { Economics and project } \\
\text { management }\end{array}$} & & ENGN101 & ENGN201 & & & & ENGN401 & MECH499 \\
\hline & & & & & & & MECH498 & \\
\hline \multirow{3}{*}{ Life-long learning } & ENGN100 & ENGN101 & & MECH207 & & МЕСH308 & MECH498 & MECH499 \\
\hline & & & & & & & & \\
\hline & & & & & & & & \\
\hline
\end{tabular}

$1^{\text {th }}$ LACCEI Annual International Conference: "Engineering Education Facing the Grand Challenges, What Are We Doing?" 
As an example of how AUs and GrAtts are reported for courses, the first-year Technical Communications course contains Complementary Studies for $75 \%$ of its hours and Engineering Design for $25 \%$ of its hours. As well, it assesses students' skills in the GrAtts problem analysis, design, use of engineering tools, individual and team work, communication skills, professionalism, ethics and equity, economics and project management, and life-long learning. Fig. 1 shows a diagram of how Technical Communications contributes to the two systems of measure for undergraduate engineering program accreditation, AUs and GrAtts.

\section{IMPLICATIONS OF ACCREDITATION}

The engineering accreditation process in Canada is a valuable exercise which ensures uniformity and adherence to standards across the engineering schools in the nation. It provides a feedback mechanism to the institutions to improve and adjust their curriculum to meet societal needs. On the other hand, it imposes certain restrictions at the global (international) level.

Representatives from other countries visiting Canadian schools find it rather shocking that there are so many obstacles to setting up transfer/exchange agreements between institutions in engineering. Very often foreign universities seek a $2+2$ agreement allowing their engineering students to complete two years at their home institutions and then to complete their engineering degrees in Canada with an additional two years. To this date, there is not a single agreement of this type existing. This by no means reflects the "quality" of the overseas institution, but is simply not achievable because of the accreditation requirements in Canada.

As mentioned previously, there is not currently any requirement to show that all students have achieved a certain skill-level for the GrAtts; however, it must be demonstrated that every student has successfully completed courses such that a minimum number of hours of each of the five AUs have been achieved. This minimum path criteria can affect the technical electives that students may take. It also greatly affects the amount of transfer credit that students can receive when transferring from other institutions. Although course topics may be similar between institutions, any course for which there are Engineering Science or Engineering Design hours, a transfer student must show that the relevant course(s) taken at his/her prior institution were taught by a professional engineer licensed in Canada.

At the personal level, transferring students from outside of Canada find it frustrating and unfair that they will have to repeat some of the engineering courses that they have already passed with high marks. However, there is no immediate solution to such matters and it is unlikely to change in the near future.

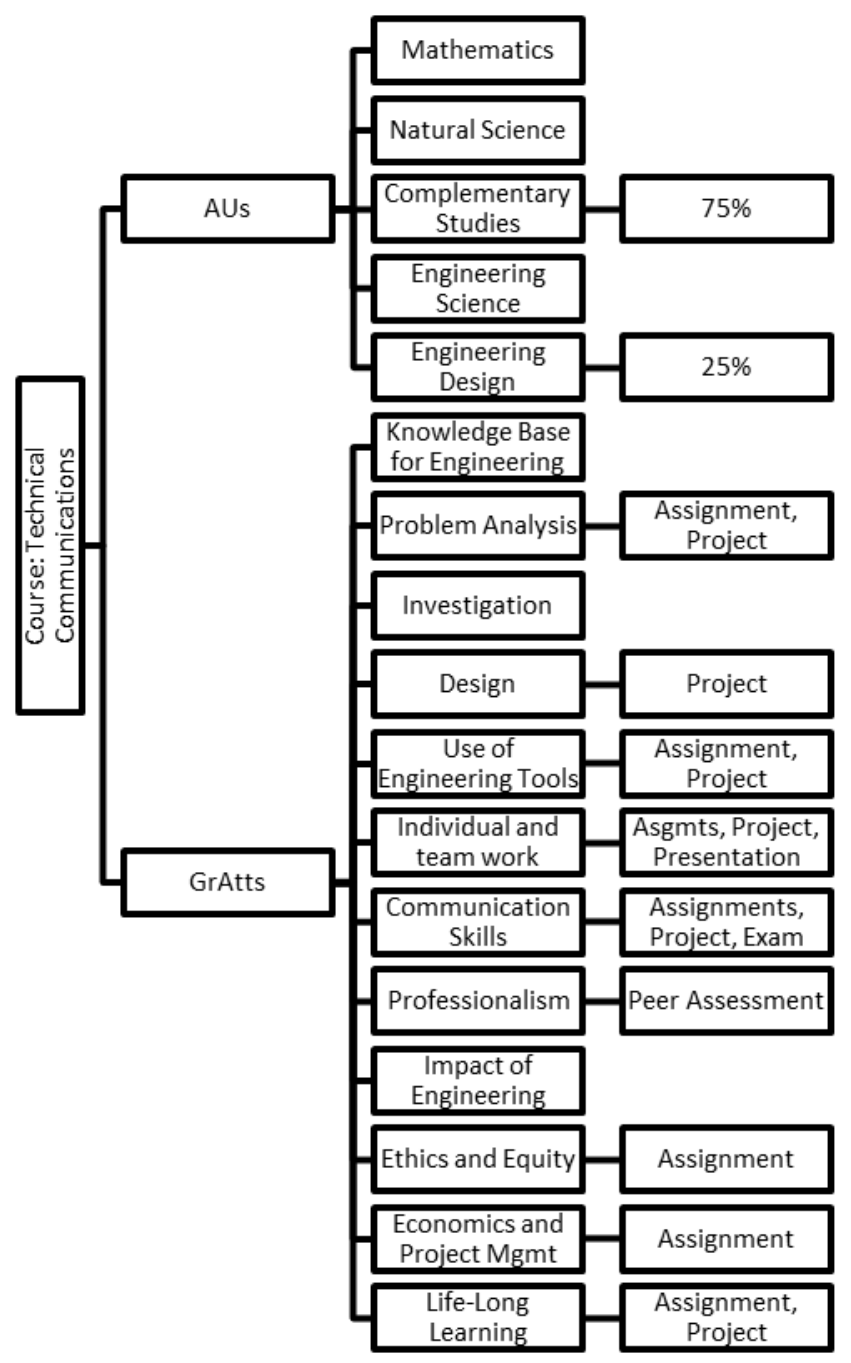

Fig. 1 Contribution to AUs and GrAtts for Technical Communications course. 
The Canadian Engineering Accreditation Board (EngineersCanada) has signed a number of agreements with the national engineering organizations in other countries. The agreement with Costa Rica (Colegio Federado de Ingenieros y Arcquitectos de Costa Rica) is a memorandum of understanding which commits CEAB to provide support and advice for establishing engineering accreditation in that country. Perhaps activities such as these will enable future transfer agreements between accredited Canadian undergraduate engineering programs and accredited (within the jurisdiction of the institution) international undergraduate engineering programs.

\section{REFERENCES}

[1] Professional Engineers Ontario, Toronto, Ontario, http://www.peo.on.ca, 2015

[2] EngineersCanada, Ottawa, Ontario, http://www.engineerscanada.ca/., 2015

[3] Accreditation Board of Engineering and Technology, ABET, http://www.abet.org/

[4] Canadian Engineering Accreditation Board, Accreditation Criteria and Procedures, Ottawa, Ontario, 2013.

$1^{\text {th }}$ LACCEI Annual International Conference: “Engineering Education Facing the Grand Challenges, What Are We Doing?" July 29-31, 2015, Santo Domingo, Dominican Republic 